\title{
Verification of the precision of GSM and GPS signals available on mobile devices
}

\section{Weryfikacja dokładności sygnałów GSM i GPS dostępnych na urządze- niach mobilnych}

\author{
Mateusz Wlaź*, Grzegorz Kozieł*
}

Department of Computer Science, Lublin University of Technology, Nadbystrzycka 36B, 20-618 Lublin, Poland

\begin{abstract}
The research work presents the study of the quality of telecommunications and satellite signals. For this purpose, a proprietary application for mobile devices has been designed, which allowed the collection data. The tests were performed on several models of cell phones and for different operators. The test checked the impact of such things as weather conditions, device architecture, device age, type of terrain. Based on the results, heat maps were created to visualize the research.
\end{abstract}

Keywords: quality of signal; mobile devices; telecommunications signal; satellite signal

\section{Streszczenie}

Praca badawcza prezentuje badanie jakości sygnału telekomunikacyjnego oraz satelitarnego. W tym celu zaprojektowano autorską aplikację na urządzenia mobilne, która umożliwiła gromadzenie danych. Badania wykonano na kilku modelach telefonów komórkowych oraz dla różnych operatorów. W badaniu sprawdzono wpływ na sygnał takich czynników jak: warunki atmosferyczne, architektura urządzenia, wiek urządzenia, rodzaj terenu. Na podstawie wyników stworzono mapy cieplne w celu wizualizacji badań.

Słowa kluczowe: jakość sygnału; urządzenia mobilne; sygnał telekomunikacyjny; sygnał satelitarny

${ }^{*}$ Corresponding author

Email addresses: mateusz.wlaz@pollub.edu.pl, (M. Wlaź), g.koziel@pollub.pl (G. Kozieł)

CPublished under Creative Common License (CC BY-SA v4.0)

\section{Wstęp}

Co roku obserwowany jest znaczący spadek liczby telefonów stacjonarnych [1,2,3]. Są one systematycznie wypierane przez telefony komórkowe. Obecnie liczba kart sim obsługiwanych przez polskich operatorów telekomunikacyjnych przekracza liczbę mieszkańców Polski $[4,5]$. Świadczy to o dużej intensywności użytkowania urządzeń mobilnych oraz o znaczącym zapotrzebowaniu na tego typu usługi. Ponad 92\% Polaków wykorzystuje telefony komórkowe [6]. Są one najczęściej używane do prowadzenia rozmów i wysyłania wiadomości [6].

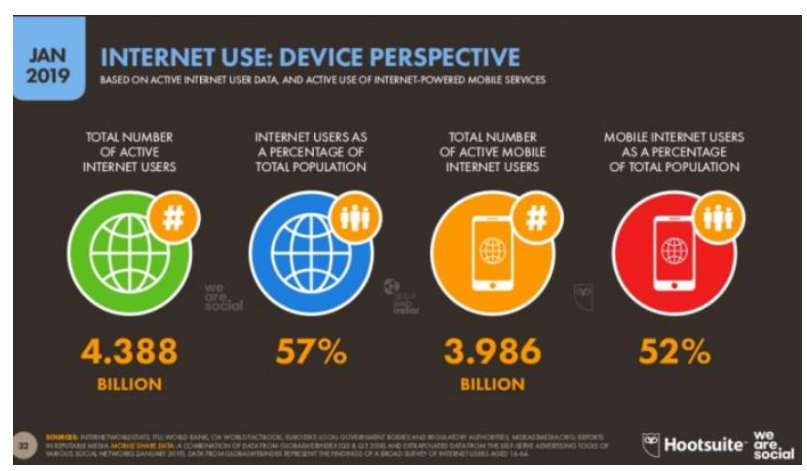

Rysunek 1: Dane o użytkownikach Internetu [7].

Nie można jednak pominąć innych zastosowań, wśród których dominują usługi dostępne w Internecie.
$52 \%$ populacji świata uzyskuje dostęp do Internetu za pomocą smartfonów (Rys.1) [7]. $42 \%$ korzysta na smartfonach z mediów społecznościowych.

Oczywiście zastosowania urządzeń mobilnych są o wiele szersze, o czym świadczyć może chociażby ogromna liczba różnorodnych aplikacji dostępnych dla urządzeń mobilnych [8]. Jednak poprawne działanie wielu $\mathrm{z}$ nich uwarunkowane jest dobrą jakością połączenia z Internetem oraz precyzją lokalizacji urządzenia. Dane operatorów dostępne na ich stronach [9] prezentują poglądowo zasięg sygnału i dostępność poszczególnych usług. Nie wskazują jednak siły sygnału ani też jakości połączenia (Rys. 2).

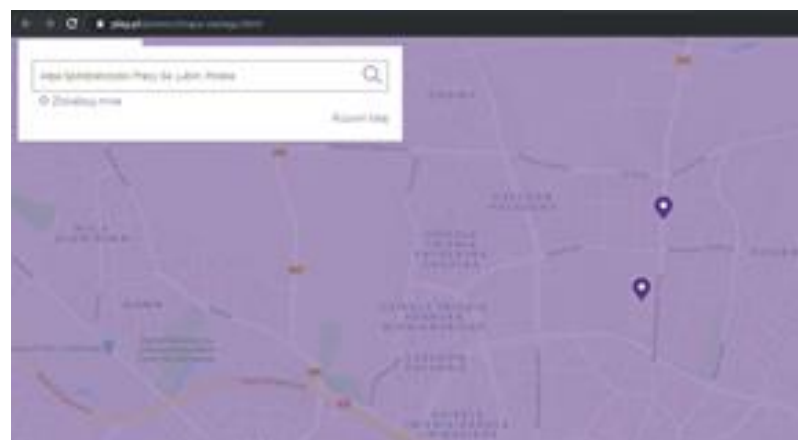

Rysunek 2: Mapa zasięgu sygnału LTE operatora Play [9].

Te jednak mogą się znacząco zmieniać w zależności od obszaru czy typu terenu. Zależność tą można 
z powodzeniem zaobserwować na mapach prezentowanych przez aplikację RFBenchmark (Rys. 3).

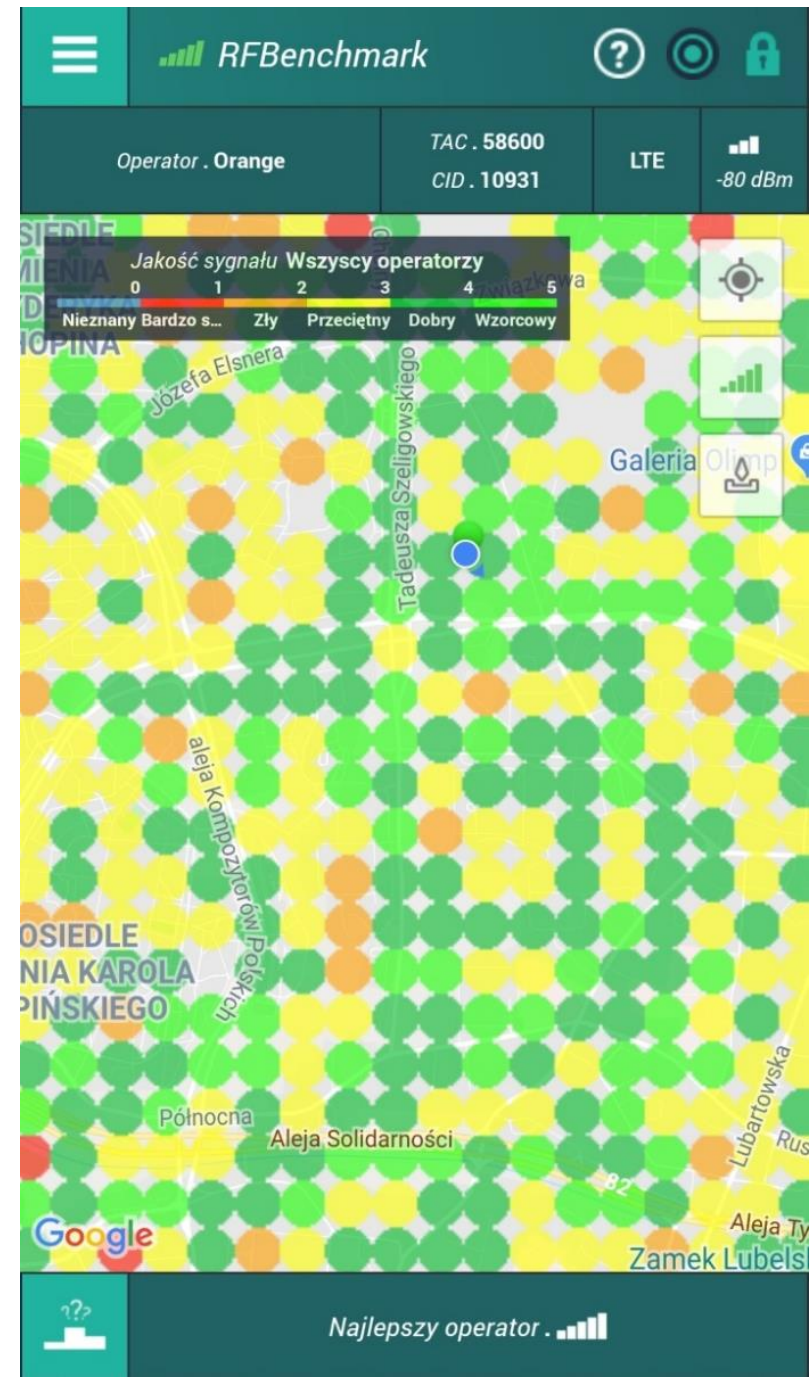

Rysunek 3:. Jakość sygnału GSM na wybranym terenie.

Ze względu na zaobserwowane problemy ze słabą jakością sygnału GSM i GPS autorzy postanowili przeprowadzić badania pozwalające na weryfikację jakości wymienionych sygnałów na wybranych obszarach. W tym celu stworzona została autorska aplikacja pracująca pod kontrolą systemu operacyjnego Android. Posłużyła ona do zmierzenia dostępnego poziomu badanych sygnałów i zapisania wyników badań w bazie danych. Uzyskane wyniki zostały następnie przeanalizowane i zaprezentowane w niniejszym artykule.

\subsection{Infrastruktura sieci telefonii komórkowej}

Systemy, które są obecnie użytkowane bazują na technologiach drugiej, trzeciej oraz czwartej generacji. Każda z podanych generacji różni się między sobą wynikami dotyczącymi ich specyfikacji wynikającej z budowy takiej technologii (Rys. 4).

Użytkownik sieci znajdujący się w elemencie zwanym komórką (szare sześciokąty) kontaktuje się $\mathrm{z}$ innym użytkownikiem poprzez BS (ang. Base Station), czyli maszty ujęte na komórkach. Stacje bazowe (BS) zarządzane są poprzez BSC (ang. Base Station Control- ler), które przekazują dane dalej do sieci szkieletowej komunikując się z MSC (ang. Mobile Switching Centre). MSC sa to cyfrowe centrale telefoniczne, które odpowiadają za zestawianie ze sobą połączeń. Dodatkowym elementem mieszczącym się w sieci szkieletowej jest HLR (ang. Home Location Register), czyli baza danych, która przechowuje dane o użytkownikach i zezwala lub odrzuca możliwość korzystania $\mathrm{z}$ danych zasobów radiowych.

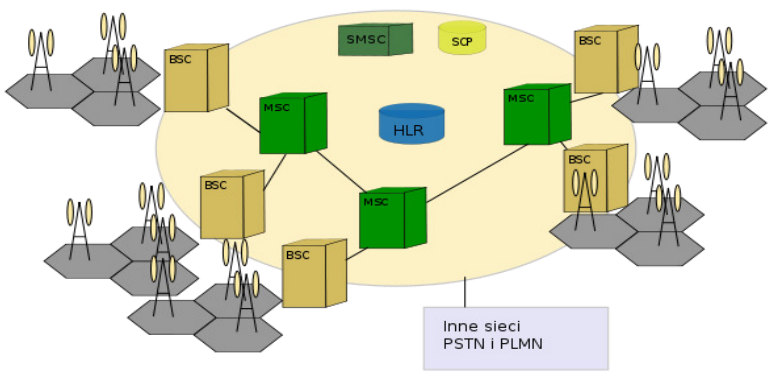

Rysunek 4: Architektura sieci dla trzeciej generacji [10].

\subsection{Sygnały GSM i GPS}

Sygnał jest to zmienność wielkości fizycznej W wielkości zmieniającej się (czyli najczęściej czasie). Dla telekomunikacji sygnały są to nośniki informacji przekazywanych na dowolne odległości.

GPS (ang. Global Positioning System) jest to system nawigacyjny służący lokalizacji na lądzie, morzu czy w powietrzu. Pozwala on na otrzymanie takich danych jak położenie, aktualna prędkość $\mathrm{z}$ jaką obiekt się porusza. W skrócie system nazywany jest jako GPS, który został stworzony przez Stany Zjednoczone i po raz pierwszy w pełni użyto go w 1978 roku. Początkowo system ten miał służyć tylko dla celów militarnych, chociażby do naprowadzania pocisków na konkretny cel jednak szybko został on wprowadzony do codziennego użytku cywilnego.

System stworzono na podstawie trzech segmentów:

- kosmiczny (satelity krążące wokoło Ziemi)

- kontroli (monitorowanie stacji kontrolnych znajdujących się na równiku)

- użytkownika (wykorzystanie technologii GPS w codziennym życiu).

GSM (ang. Global System for Mobile Communications) jest to standard telefonii komórkowej należącej do drugiej generacji sieci komórkowych (2G). Po raz pierwszy dla tej generacji użyto technologii cyfrowej (1G oparto na technologii analogowej). W Polsce 2G pojawiło się w 1996 roku, umożliwiając nie tylko wykonywanie połączeń ale również możliwość wysyłania SMS, a nawet na łączność z Internetem poprzez urządzenie mobilne.

\subsection{Metodyka badawcza}

Badanie sygnałów polegało na wykorzystaniu autorskiej aplikacji na urządzenia mobilne w celu zgromadzenia potrzebnych danych. Wykonano dwa rodzaje badań: dla sygnałów telekomunikacyjnych oraz satelitarnych. Badania zostały powtórzone kilkakrotnie na 
różnych modelach urządzeń mobilnych (Huawei P20 Lite, Huawei P9 Lite, Huawei P10 Lite, Samsung Galaxy A40, Samsung Galaxy Tab 4).

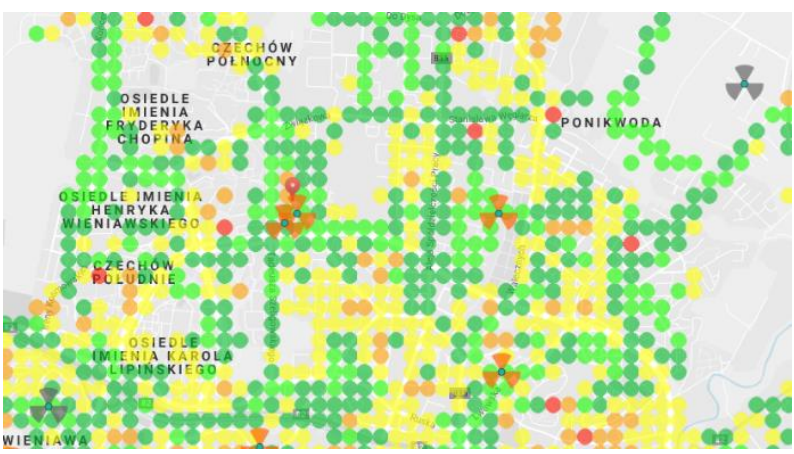

Rysunek 5: Mapa zasięgu aplikacji RFBenchmark.

Porównując mapę zasięgu operatora oraz mapę zasięgu otrzymaną przy użyciu aplikacji RFBenchmark, można zauważyć różnicę $\mathrm{w}$ wynikach. Operator nie określa dokładności czy mocy sygnału, który jest oferowany w danej lokalizacji. Przedstawia on tylko fakt występowania zasięgu w danej lokalizacji (Rys. 2). Mapa zasięgu pozyskana $\mathrm{z}$ aplikacji RFBenchmark nie odzwierciedla jednak pokrycia zasięgu przedstawionego przez operatora. Wybierając opcję zasięgu tylko dla sygnału LTE, występują miejsca, w których nie ma zasięgu (Rys. 5). W celu weryfikacji poprawności otrzymanych danych stworzono autorską aplikację.

Dla sygnału satelitarnego wartości, które pobrano są to:

- długość geograficzna - współrzędna opisująca kąt pomiędzy południkiem 0 , a aktualnym południkiem

- szerokość geograficzna - tak jak długość geograficzna jest to współrzędna opisująca kąt pomiędzy płaszczyzną równika, a obecnym równoleżnikiem

- dokładność - parametr wyrażony w badaniu w metrach, określa przybliżoną dokładność urządzenia

- prędkość - prędkość poruszania się podczas badania, wyrażona w metrach na sekundę

- wysokość - wysokość nad poziom morza, mierzona w metrach

- Sygnał telekomunikacyjny określony został poprzez:

- sila odbieranego sygnału - wskaźnik siły odbieranego sygnału, mierzona w wartościach ujemnych $\mathrm{dBm}$

- Level - abstrakcyjna jakość sygnału opisywana wartością od 0 do 4

- ASU (ang. Arbitrary Strength Unit) - jest to wskaźnik, który jest liczbą całkowitą, która jest proporcjonalna do siły odbieranego sygnału

Tabela 1. Tabela opisująca jakość sygnału dla 2G [11].

\begin{tabular}{|l|l|}
\hline RSSI & Jakość \\
\hline$>-52 \mathrm{dBm}$ & Doskonała \\
\hline$-53 \mathrm{dBm}$ do $-109 \mathrm{dBm}$ & Dobra \\
\hline$-110 \mathrm{dBm}$ do $-112 \mathrm{dBm}$ & Dostateczna \\
\hline$<-113 \mathrm{dBm}$ & Słaba \\
\hline$<=-110 \mathrm{dBm}$ & Brak sygnału \\
\hline
\end{tabular}

Jakość sygnału została określona w standardach dotyczących sygnału GSM (Tabela 1). Każda technologia posiada stworzoną specyfikację, która określa dopuszczalne wartości siły sygnału oraz zasady funkcjonowania tych technologii. Im bliżej $0 \mathrm{dBm}$, tym lepszy jest sygnał.

Dla 2G wartość ASU określana jest jako RSSI (ang. Received Signal Strength Indicator) i wyliczana na podstawie poniższego wzoru:

$$
d B m=2 \times A S U-113
$$

Badanie zostało podzielone na dodatkowe dwa rodzaje: mobilne (zostały przemierzone wybrane ulice Lublina wraz z kilkoma urządzeniami) oraz stacjonarne (pomiary wykonywane podczas znajdowania się urządzenia w tej samej lokalizacji).

\subsection{Stanowisko badawcze}

Badania wykonane zostały na urządzeniach mobilnych, czyli Huawei P20 Lite, Samsung Galaxy A40, Huawei P10 Lite, Huawei P9 Lite, Samsung Galaxy Tab 4. Pierwsze trzy urządzenia należą do grupy nowszych urządzeń (2017 i nowsze). Na wszystkich urządzeniach została zainstalowana autorska aplikacja, która służyła do gromadzenia danych dotyczących sygnałów.

Wykonano dwa rodzaje badań: stacjonarne, w którym urządzenia znajdowały się w jednej lokalizacji przy oknie i nie były użytkowane podczas badań. Drugie mobilne, czyli przejazd wyznaczoną trasą po Lublinie. Wszystkie badania zostały powtórzone kilkakrotnie.

\section{Eksperyment}

Celem przeprowadzenia badań naukowych było porównanie i zweryfikowanie faktycznego stanu jakości sygnałów telekomunikacyjnych oraz satelitarnych. W tym celu wykonano kilka badań w celu uzyskania wyników, które można przeanalizować oraz zaprezentować w formie wykresów lub map cieplnych. Badania zostały powtórzone kilkakrotnie, aby można było mówić o powtarzalności wyników.

Poniższe badania przedstawiają częściowe wyniki prac nad sprawdzeniem jakości sygnałów GSM oraz GPS.

\subsection{Sila sygnału GSM w stałej lokalizacji}

Celem tego badania było sprawdzenia jakości sygnału dla dwóch operatorów telekomunikacyjnych: Play oraz Orange. Wyniki uwzględniają warunki pogodowe. Badanie wykonano dla sieci drugiej generacji.

Wyniki badania (Rys. 6) są to wyniki z jednej doby (wyniki zostały przeskalowane w taki sposób, że punkt 0 to godzina 00:00), badanie zostało przeprowadzone w bloku znajdującym się na osiedlu. Telefony ( 2 jednakowe modele: Samsung Galaxy A40) podczas pomiarów znajdowały się w jednej lokalizacji. Przedstawione badanie zostało powtórzone kilkakrotnie dla jak najdokładniejszych wyników.

Na rysunku 6 można wyraźnie zauważyć wzrost jakości sygnału w godzinach 7-17. Badanie wykazuje, że jakość sygnału na terenie pomiaru prawie przez cały okres jego trwania była lepsza dla sieci Play. 


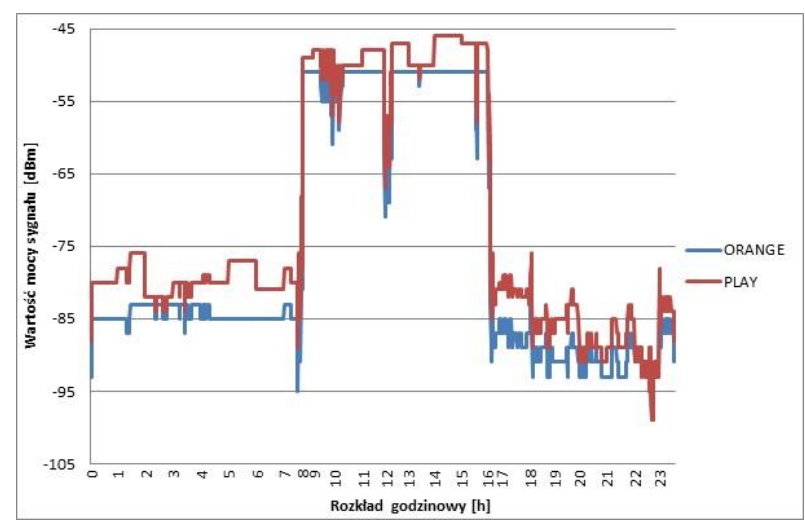

Rysunek 6: Wykres mocy sygnału 2G dla operatorów.

\subsection{Rozkład sily sygnału GSM na wybranych dro- gach}

Celem tego badania było przeprowadzanie badań podczas poruszania się pojazdem po określonych trasach miasta Lublin. W badaniu wykorzystano dwóch operatorów Play oraz Orange. W celu jak najdokładniejszego przeprowadzenia badań poniższe wykresy zostały przedstawione dla tego samego modelu telefonu (Samsung Galaxy A40) oraz prace badawcze wykonywano w tym samym czasie, aby wyeliminować możliwość wpływu czynników zewnętrznych na wyniki badania.

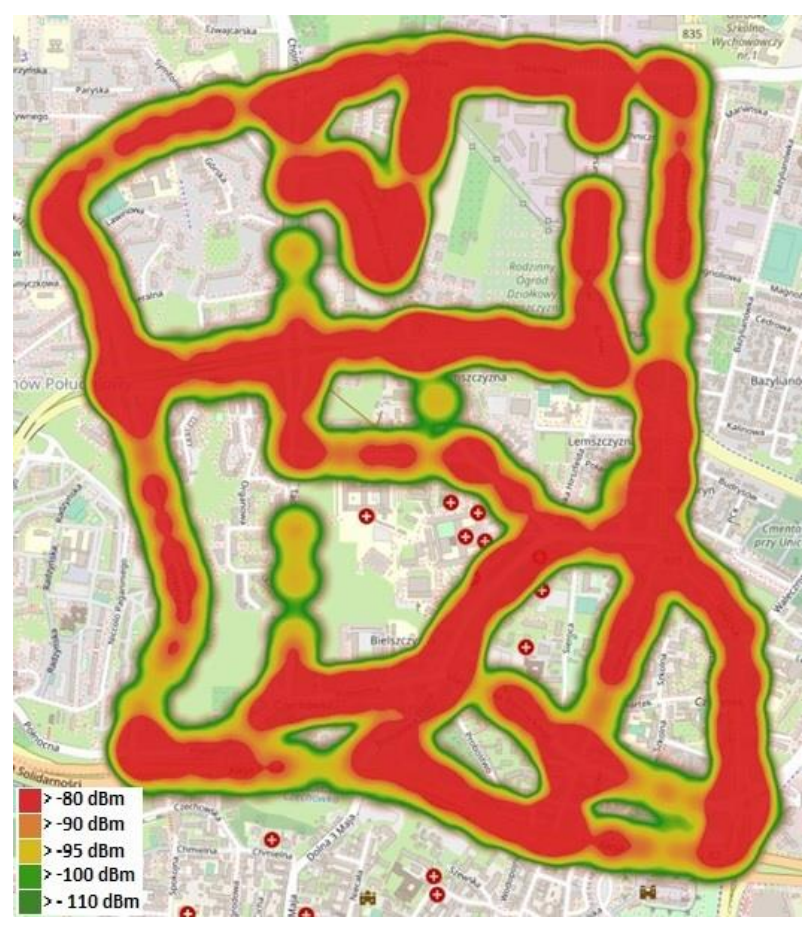

Rysunek 7: Mapa cieplna mocy sygnału GSM dla Orange.

Powyższa mapa cieplna (Rys. 7) przedstawia wynik badania dla poruszania się głównymi drogami badanej części Lublina. Pomiary zostały powtórzone pięciokrotnie, a wykres został stworzony na podstawie ich średnich wartości. Niniejsze badanie ukazuje wynik jakości sygnału sieci dla operatora Orange. Im bardziej czerwone zaznaczenie tym moc sygnału w danym miejscu była większa.

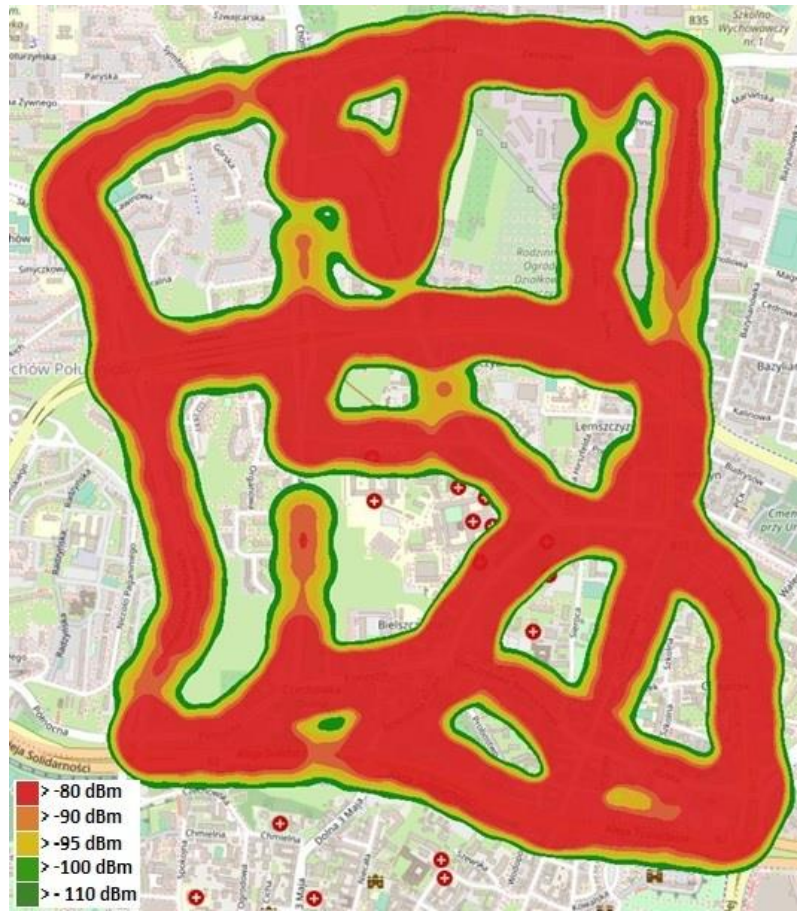

Rysunek 8: Mapa cieplna mocy sygnału GSM dla Play.

Mapa cieplna (Rys. 8) przedstawia jakość sygnału dla operatora komórkowego Play. Podobnie jak w powyższym przykładzie badanie przeprowadzono, przemierzając główne drogi Lublina. Czerwony kolor oznacza najlepszą wartość sygnału.

$\mathrm{Na}$ podstawie przedstawionych map cieplnych można określić, że operator sieci Play dla drugiej generacji posiada lepsze pokrycie terenu oraz lepszą jakość sygnału.

\subsection{Jakość sygnału GPS w stałej lokalizacji}

Celem tego badania było przeprowadzenie sprawdzenia jakości sygnału dla systemu nawigacji w warunkach stacjonarnych. Wyniki uwzględniają warunki pogodowe. Badanie wykonano dla systemu GPS. Powtórzone zostało na kilku modelach telefonów.

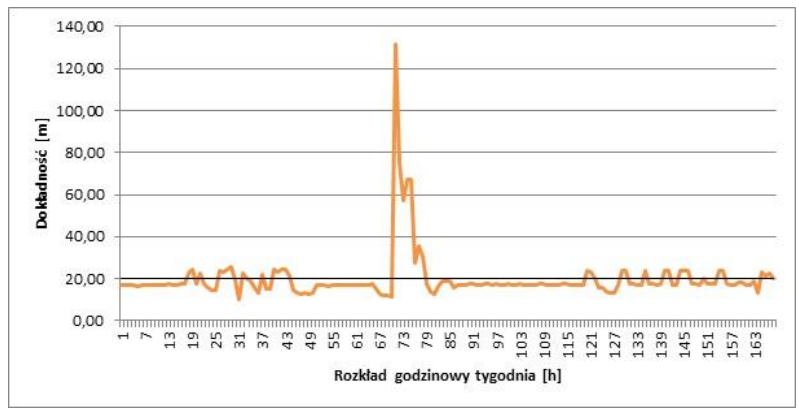

Rysunek 9: Wykres dokładności GPS względem rozkładu godzinowego dla tygodnia.

Przedstawiony wynik badania (Rys. 9) prezentuje dokładność sygnału satelitarnego, podawaną w metrach w stosunku do rozkładu godzinowego w ciągu tygodnia. Wykres został przeskalowany w taki sposób, aby początkowa godzina pomiaru (punkt 0 na osi rozkładu godzinowego) był to dzień odpowiadający północy 
z niedzieli na poniedziałek. Każde kolejne 24 godziny to jeden dzień tygodnia. Badanie zostało przeprowadzone w mieszkaniu i powtórzono na Samsung Galaxy A40, Huawei P20 Lite oraz Samsung Galaxy Tab 4.

Jak można zauważyć z powyższego wykresu dokładność sygnału w ciągu tygodnia oscyluje w granicach 20 metrów. Jednak od godziny 72 do 78 występuje bardzo duży skok dokładności, sięgający 130 metrów. W tym okresie w danej okolicy występowała bardzo silna burza, można więc na tej podstawie określić, że złe warunki atmosferyczne mają znaczący wpływ na jakość sygnału satelitarnego co za tym idzie również na jego dokładność. Podobny skok widoczny jest również na innych urządzeniach, na których w danym momencie były prowadzone pomiary.

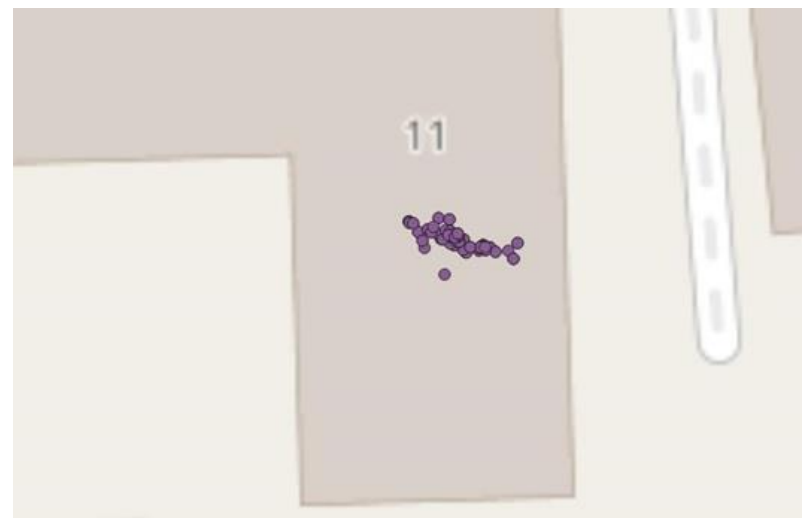

Rysunek 10: Wizualizacja punktów pomiarowych dla Huawei P20 Lite.

Przedstawione pomiary (Rys. 10 oraz Rys. 11) przedstawiają sytuację dla pomiaru stacjonarnego i ukazują dokładność sygnału satelitarnego. Urządzenia podczas badania znajdowało się ciągle w mieszkaniu w okolicach okna. Badania zostały wykonywane w tym samym czasie, aby nie można było mówić o wpływie różnych czynników zewnętrznych. Wyniki badania powstał przez nałożenie punktów $\mathrm{z}$ długości oraz szerokości geograficznej na mapę.

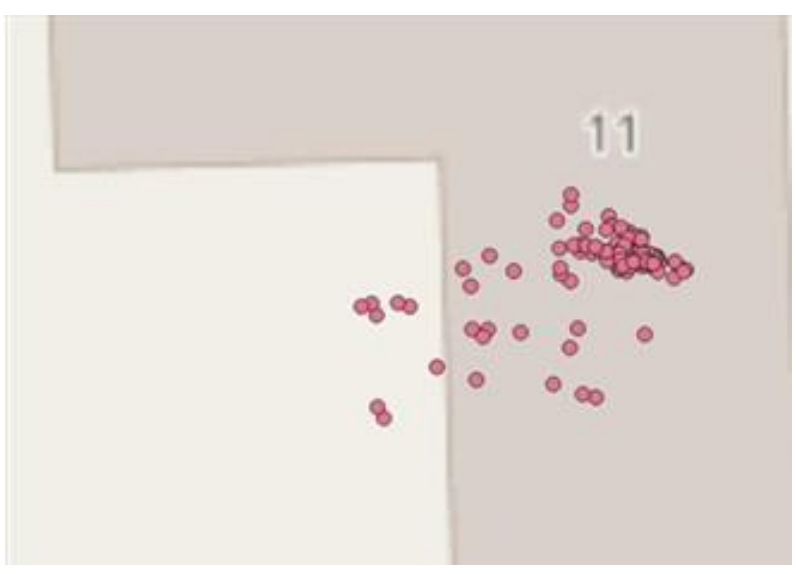

Rysunek 11: Wizualizacja punktów pomiarowych dla Samsung Galaxy Tab 4.

Okres badania jest to tygodniowy czas pomiarów. Jak można zauważyć na powyższych mapach dla Huawei P20 Lite, które jest nowym urządzeniem, dokładność sygnału jest bardzo dobra. Sygnał niemal odbiera- ny jest w jednym miejscu. Natomiast dla Samsung Galaxy Tab 4 punkty pomiarowe znacznie rozbiegają się po mapie. Można na tej podstawie sądzić, że na dokładność odbieranego sygnału ma znaczny wpływ urządzenie, z którego aktualnie korzysta użytkownik. Ciężko jednak jednoznacznie określić czy jest to wpływ architektury urządzenia czy możliwość rozstrojenia się anteny odbierającej sygnał satelitarny.

\subsection{Wpływ rodzaju terenu na dokładność GPS}

Badanie zostało wykonane w celu wykazania wpływu warunków terenu oraz otoczenia na dokładność sygnału satelitarnego. W tym celu przeprowadzone zostały następujące pomiary:

- pomiar pomiędzy wysokimi blokami, które są ustawione obustronnie wzdłuż jezdni

- pomiar pomiędzy domami jednorodzinnymi, ustawionymi obustronnie wzdłuż jezdni

- pomiar sygnału w lesie

- pomiar sygnału na pustym terenie, na którym prawie nie istnieją zabudowania oraz teren nie jest zalesiony (np. łąki)

- pomiar dokładności sygnału wraz ze wzrostem prędkości

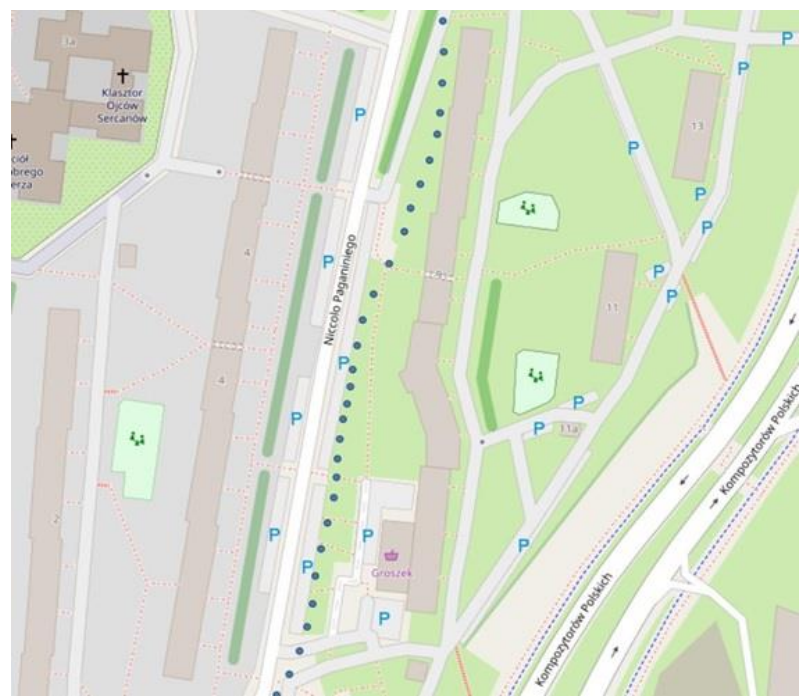

Rysunek 12: Mapa punktów pomiarowych pomiędzy blokami.

Praca badawcza przeprowadzona została na urządzeniu pomiarowym Huawei P10 Lite. Ruch odbywał się zawsze w jednym kierunku.

Mapa przedstawiona na rysunku 12 przedstawia rodzaj pomiaru wykonanego pomiędzy wysokimi blokami. Pomiar wykonano poruszając się w jednym kierunku ulicą Niccolo Paganiniego w Lublinie Jak można zauważyć naniesione punkty pomiarowe (wyznaczone na podstawie długości oraz szerokości geograficznej) znacznie odbiegają od trasy pomiaru. Średnia dokładność pomiarów wyniosła 6,83 metra.

Kolejnym etapem badania było sprawdzenie warunków działania systemu pomiędzy niższymi budynkami. W tym wypadku została wybrana osiedlowa uliczka $\mathrm{z}$ domami jednorodzinnymi. Pomiar wykonano jadąc w jedną stronę ulicą Szczęśliwą w Lublinie. 


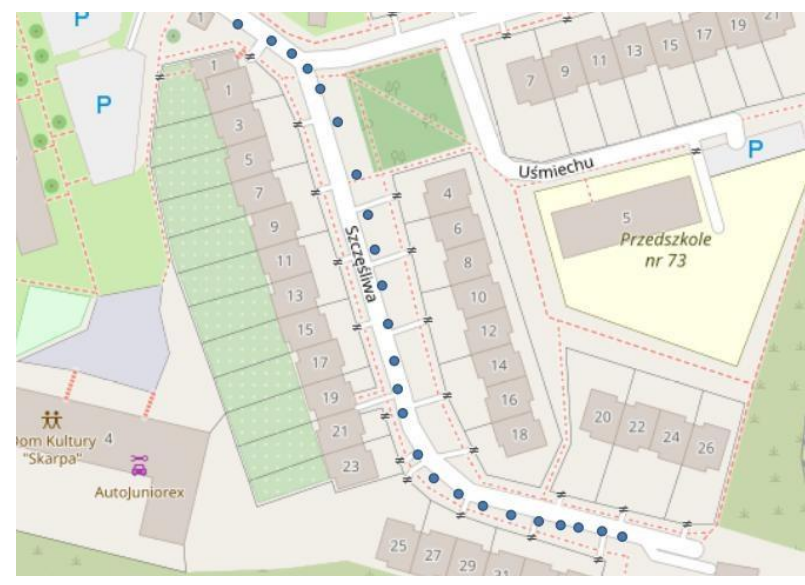

Rysunek 13: Mapa punktów pomiarowych pomiędzy domami jednorodzinnymi.

Jak można zauważyć na rysunku 13 wyniki pomiarów ponownie odbiegają od faktycznej trasy, która została przebyta. Dla tej pracy badawczej średni wynik dokładności sygnału GPS wyniósł 9,19 metra.

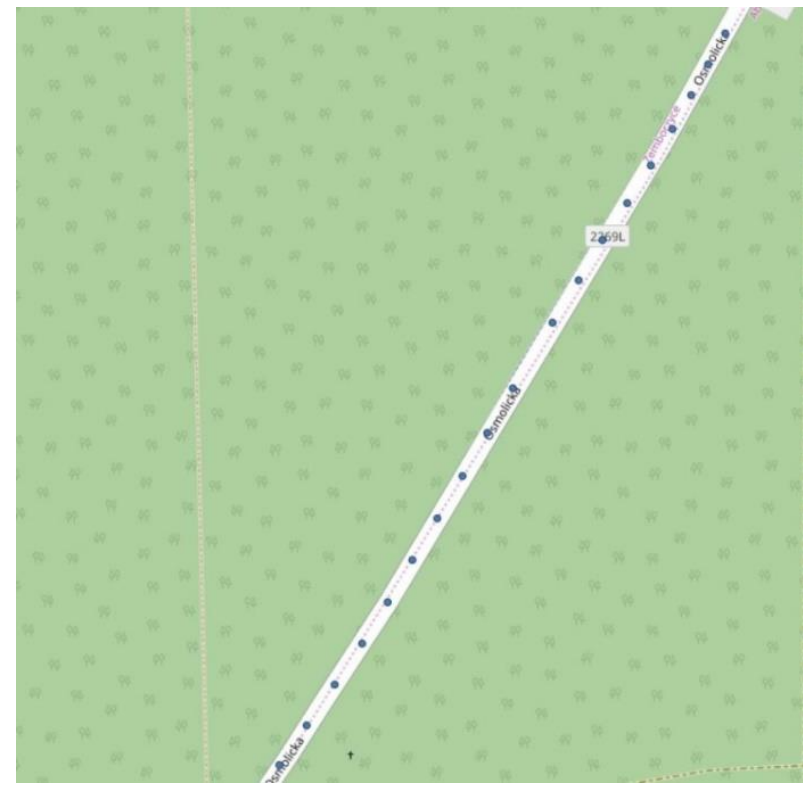

Rysunek 14: Mapa punktów pomiarowych w lesie.

Następnym etapem było sprawdzenie jakości sygnału w wysokim lesie. Podczas wykonywania pomiarów las znajdował się po obu stronach drogi. Pomiar wykonywano poruszając się w jednym kierunku ulicą Osmolicką. Jak można zauważyć na rysunku 14, wyniki pomiaru wykazują całkiem dobre odwzorowanie trasy, którą przebyto podczas badania (nie odbiega ona znacznie od prawego pasa ruchu). Średni wynik dokładności sygnału dla tego pomiaru wyniósł 4,85 metra.

Przedostatnią pracą badawczą, która została wykonana był test jakości sygnału na terenie, na którym prawie nic się nie znajduje. Trasę przebyto $\mathrm{w}$ jednym kierunku, jej odwzorowanie na mapie zostało zaprezentowane na rysunku 15. Badanie wykazało, że średnia dokładność dla takiego rodzaju terenu wyniosła 4,71 metra.

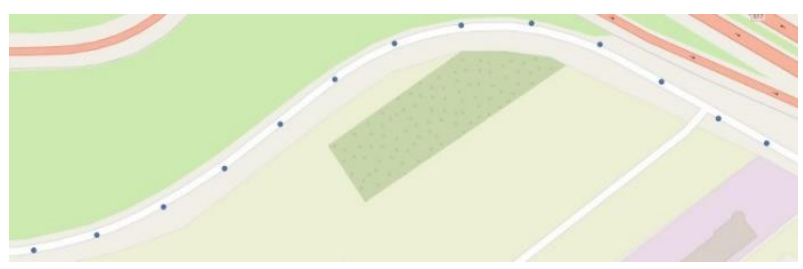

Rysunek 15: Mapa punktów pomiarowych na pustym terenie

Ostatnią próbą badawczą, która została wykonana to sprawdzenie wpływu prędkości na jakość sygnału GPS. W tym celu wykonano pomiar na trasie szybkiego ruchu. Pomiary wykonane dla prędkości od 60 do 120 kilometrów na godzinę z interwałami co 10 kilometrów na godzinę. Dla każdego pomiaru wykonano 20 próbek co 50 metrów na podstawie, których wyliczono średnią dokładność sygnału satelitarnego. Badanie wykazało niezmienność jakości sygnału GPS w zależności od prędkości poruszania się (Rys. 16), jedynie przy prędkości 90 kilometrów na godzinę wystapił delikatny spadek średniej dokładności. Jest to jednak bardzo niewielka różnica (0,06 metra).

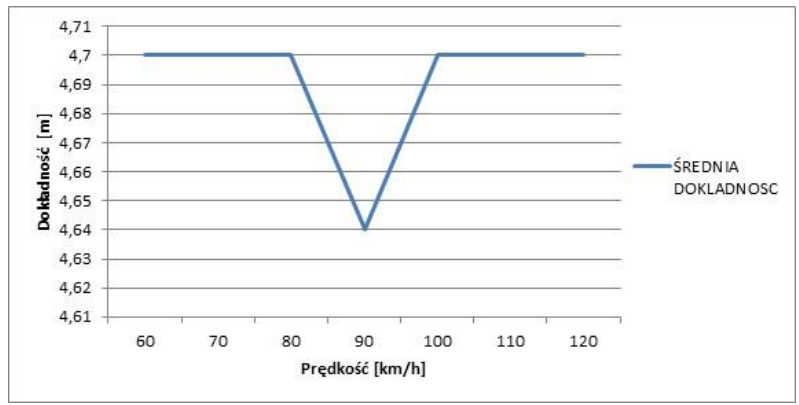

Rysunek 16: Wykres prędkości do dokładności sygnału GPS.

\section{Wnioski}

W ramach tej pracy wykonano badania dotyczące pomiaru jakości sygnałów telekomunikacyjnych oraz dodatkowo wykonano testy dokładności sygnału satelitarnego. W tym celu została stworzona aplikacja służąca do gromadzenia wyżej wymienionych danych.

Operatorzy komórkowi nie informują użytkowników o faktycznych i dokładnych stanach sieci jakie mogą uzyskać tylko podają im teoretyczną wiedzę czy na danym terenie będą posiadali zasięg. Takie podejście operatorów skutkuje często znanymi sytuacjami, podpisania umowy z operatorem, a następnie rozwiązywania jej z powodu braku dostępu do sieci.

Operatorzy podczas podawania takich danych powinni brać pod uwagę warunki atmosferyczne oraz natężenie ruchu sieci, ponieważ jakość sygnału w tym momencie ulega pogorszeniu. Na wyniki zaprezentowane w powyższej pracy badawczej mogą mieć wpływ chociażby rodzaje aparatów, z których użytkownik korzysta. W aparatach telefonicznych występuje efekt rozstrajania się anten, dlatego na urządzeniach, które przepracowały więcej godzin wyniki odróżniają się od badań przeprowadzonych na nowszych urządzeniach. Średnia różnica wartości między nowszym, a starszym modelem to około $10 \mathrm{dBm}$. 
Dla sygnałów telekomunikacyjnych można zauważyć poprawienie jakości sygnału w godzinach 7-17. W godzinach 17-7 średnia wartość siły sygnału wynosi około -110dBm, natomiast w godzinach 7-17 plasuje się ona na poziomie około $-80 \mathrm{dBm}$. Może to być powodem użycia techniki regulacji mocą w momencie kiedy liczba użytkowników wzrasta [12]. W pobliżu miejsca pomiaru stacjonarnego znajduje się wiele budynków użyteczności publicznej (policja, szpital) oraz biura firm informatycznych. Wraz ze wzrostem użytkowników operator zwiększa moc wysyłanego sygnału co powoduje wzrost jakości sygnału.

Dla sygnału satelitarnego można zauważyć problemy z jakością sygnału w gorszych warunkach atmosferycznych. Powszechnie panuje informacja, że warunki atmosferyczne nie mają wpływu na jakość sygnału satelitarnego. Na podstawie badania można stwierdzić, że złe warunki nie mają jednoznacznie wpływu na brak sygnału, ponieważ nawet przy bardzo złej pogodzie sygnał wciąż był dostępny. Jednak warunki atmosferyczne wpływają na pogorszenie sygnału co przekłada się na pogorszenie dokładności. W budynku w trakcie burzy dokładność spadała nawet do 130 metrów, gdzie przy normalnych warunkach atmosferycznych wynosiła około 15 metrów.

Dla wyników dotyczących dokładności sygnału satelitarnego można dojść do wniosku, że otoczenie, w którym znajduje się użytkownik ma bardzo duże znaczenie na dokładność sygnału GPS. W przypadku terenów znajdujących się blisko zabudowań dokładność jest gorsza niż dla terenu, na którym nic się nie znajduje. Dla pomiarów pomiędzy blokami średnia dokładność wynosiła 6,83 metra, na osiedlu domków jednorodzinnych osiągnięto dokładność rzędu 9,19 metra. Dokładność w lesie wyniosła 4,85 metra, a na pustym terenie 4,71 metra.

W badaniu wykazano również, że jakość użytych urządzeń ma wpływ na wyniki pomiarowe sygnałów telekomunikacyjnych. Na starszych urządzeniach wyni- ki pomiarów są gorsze. W badaniu nie wykazano jednak jakichkolwiek znaczących różnic $w$ porównaniu do wersji oprogramowania urządzenia. Badanie wykonano na dwóch jednakowych modelach $\mathrm{z}$ różnymi wersjami oprogramowania oraz dla wyeliminowania błędów wykonano badanie powtórnie na tym samym modelu aparatu $\mathrm{z}$ różnymi systemami.

\section{Literatura}

[1] https://wiadomosci.dziennik.pl/wydarzenia/artykuly/7967 4,polacy-masowo-oddaja-telefony.html [25.10.2019]

[2] https://komorkomania.pl/21420,komorki-uparciewypieraja-telefony-stacjonarne [25.10.2019]

[3] https://www.money.pl/gielda/uke-liczba-abonentowtelefonii-stacjonarnej-spadla-do-4-1-mln-w-2018-r6396870592546433a.html [25.10.2019]

[4] https://www.parkiet.com/Analizy/305159869-Liczbakart-SIM-W-I-kwartale-2019-roku-na-rynku-telefoniikomorkowej-w-Polsce-widac-stabilizacje-bazklientow.html [25.10.2019]

[5] https://mobirank.pl/2019/02/01/raport-mobile-i-digitalna-swiecie-w-2019-roku/ [25.10.2019

[6] https://technologia.dziennik.pl/internet/artykuly/555355,s ondaz-telefony-komrkowe-smartfony.html [25.10.2019]

[7] https://www.mobiletrends.pl/raport-cyfrowy-wzrost-w2019-roku/[25.10.2019]

[8] https://play.google.com/store/apps?hl=pl [25.10.2019]

[9] https://www.play.pl/pomoc/mapa-zasiegu.htm] [29.10.2019]

[10] https://bankowymokiem.pl/posts/cdma-co-to-zatechnologia-i-do-czego-mozna-ja-wykorzystac [29.10.2019]

[11] https://www.etsi.org/deliver/etsi_gts/07/0707/05.00.00_6 0/gsm ts_0707v050000p.pdf [17.11.2019]

[12] http://malopolska.btsearch.pl/PM/2_4.php [29.10.2019] 